\title{
MEDIA BOOKLET DAN AUDIOVISUAL EFEKTIF TERHADAP PENGETAHUAN ORANGTUA DENGAN BALITA STUNTING
}

\section{THEEFFECTIVENESS BOOKLET AND AUDIOVISUAL MEDIATOWARD PARENTSKNOWLEDGE WITH STUNTING TODDLERS}

\author{
Juniah $^{1}$, Anita Apriliawati ${ }^{2}$, Suhendar Sulaiman ${ }^{3}$ \\ ${ }^{12}$ FakultasI lmu Keperawatan Universitas Muhammadiyah Jakarta \\ ${ }^{3}$ Program Pasca Sarjana Universitas Muhammadiyah Jakarta \\ E-mail: juniahdhz@gmail.com
}

\begin{abstract}
The Effectivenes Booklet And Audiovisual Media Toward Parentsknowledge With Stunting Toddlers. Stunting is one of the characteristics that indicates a recurring nutritional problem and in a long time, so that knowledge of parents are needed to prevent and overcome toddlers with stunting. The purpose of this study is to analyze the effect of education on caring for stunting toddlers through booklet and audiovisual media on knowledge of parents in the working area of Kota Karang Health Center. This research method used quasi experimental with the approach of pre and post-test without control. The sampling technique used purposive sampling and data analysis using paired t-test with a sample of 30 children divided into 3 groups. The population in this study were parents who had stunting toddlers aged 24-60 months. The number of samples $(\mathrm{N})=30$ consisted of 3 groups, each group there are 10 respondents. The results of the study showed a significant difference in the average of knowledge $(\mathrm{p}=0.003)$ of parents before and after the education was given through the booklet media. There are differences in the average knowledge $(p=0,000)$ of parents before and after being given education through audiovisual media. There were differences in the average knowledge $(\mathrm{p}=$ 0,000 ) of parents before and after being educated throughbooklets and audiovisual media. Booklet dan audiovisual media are more effective than using media separately. Therefore the use of booklet dan audiovisual media can be applied to health services to increase knowledge of parents.

Keywords: Audiovisual, booklet, knowledge.
\end{abstract}

\begin{abstract}
Abstrak: Media booklet dan audiovisual efektif terhadap pengetahuan orangtua dengan balita stunting. Stunting merupakan salah satu karakteristik yang menandakan terjadinya masalah gizi yang berulang dan dalam waktu yang lama, sehingga diperlukan pengetahuan orangtua untuk merawat balita dengan stunting. Tujuan penelitian ini adalah menganalisis pengaruh edukasi merawat balita stunting melalui media booklet dan audiovisual terhadap pengetahuan orangtua. Metode penelitian quasi eksperimental dengan pre and post-testawithout control. Teknik pengambilan sampel purposive sampling dan analisis data menggunakan paired t-test. Populasi dalam penelitian ini adalah orangtua yang memiliki balita stunting dengan usia24 - 60 bulan di Puskesmas Kota Karang. Jumlahsampel (N) $=30$ terdiridari3kelompok, setiap kelompok terdapat 10 responden. Hasil penelitian terdapat perbedaan signifikan rata-rata pengetahuan $(\mathrm{p}=0,003)$ sebelum dan sesudah diberikan edukasi melalui media booklet. Terdapat perbedaan rata-rata pengetahuan $(\mathrm{p}=0,000)$ orangtua sebelum dan sesudah diberikanedukasi melalui media audiovisual. Terdapat perbedaan rata-rata pengetahuan $(\mathrm{p}=0,000)$ orangtua sebelum dan sesudah diberikan edukasi melalui media booklet dan audiovisual. Media booklet dan audiovisual lebih efektif dibandingkan dengan menggunakan media secara terpisah atau sendiri - sendiri. Oleh karena itu media booklet dan audiovisual yang digabungkan jadi satu saat penyuluhan atau pendidikan kesehatan dipelayanan kesehatan untuk meningkatkan pengetahuan orangtua dapat diterapkan.
\end{abstract}

Kata kunci: Audiovisual,bookle,pengetahuan. 


\section{PENDAHULUAN}

Stunting atau anak pendek digambarkan sebagai seorang balita yang memiliki tinggi badan lebih rendah dari standar tinggi badan balita seumurnya. Stunting merupakan salah satu karakteristik yang menandakan terjadinya masalah gizi yang berulang dan dalam waktu yang lama. Kekurangan gizi dalam waktu lama itu terjadi sejak janin dalam kandungan sampai awal kehidupan anak (1000 Hari Pertama Kelahiran).Stunting juga menggambarkan status gizi kurang yang bersifat kronik pada masa pertumbuhan dan perkembangan sejak awal kehidupan. Keadaan ini dipresentasikan dengan nilai $z$-score tinggi badan menurut umur $(\mathrm{TB} / \mathrm{U})$ kurang dari -2 standar deviasi (SD) berdasarkan standar pertumbuhan (WHO, 2010).

Tahun 2017, 22,2\% atau sekitar 150,8 juta balita di dunia mengalami stunting, namun angka ini sudah mengalami penurunan jika dibandingkan dengan angka stunting pada tahun 2000 yaitu 32,6\%. Stunting di dunia lebih dari setengahnya berasal dari Asia mencapai (55\%), sedangkan lebih dari sepertiganya (39\%) tinggal di Afrika. Stunting di Asia, proporsi terbanyak berasal dari Asia Selatan $(58,7 \%)$ dari 83,6 juta balitadan proporsi paling sedikit di Asia Tengah $(0,9 \%)$. Data prevalensi balita stunting yang dikumpulkan World Health Organization (WHO), Indonesia termasuk ke dalam negara ketiga dengan prevalensi tertinggi di regional Asia Tenggara / South - East Asia Regional (SEAR). Rata-rata prevalensi balita stunting di Indonesia tahun 2005-2017 adalah 36,4\% (Kemenkes, 2018).

Berdasarkan laporan Riset Kesehatan Dasar (Riskesdas) Tahun 2018 terdapat 30,8\% balita Indonesia yang mengalami stunting. Diketahui dari jumlah prosentase tersebut terdiri dari $11,5 \%$ anak sangat pendek dan 19,3\% anak pendek. Prevalensi stunting ini mengalami penurunan namun prevalensi stunting tersebut masih berada di atas ambang batas yang ditetapkan oleh WHO yaitu sebesar 20\%, dibandingkan hasil riset kesehatan dasar (Riskesda) tahun 2013, yaitu $37,2 \%$ balita yang mengalami stunting terdiri dari $19,2 \%$ anak pendek dan 18,0\% sangat pendek. Menurut Pemantauan Status Gizi (PSG) tahun 2017, prevalensi stunting di Propinsi Lampung mencapai 31,65\% dan berada diurutan kedelapan dari 34 propinsi sedangkan urutan pertama adalah propinsi NTT dengan prosentase $40,3 \%$.

Stunting pada awal masa anak-anak diketahui memiliki tingkat kecerdasan, kemampuan motorik, dan integrasi neurosensori yang lebih rendah, sehingga akan memengaruhi kualitas kehidupan di masa usia sekolah, remaja, bahkan dewasa.Stuntingdapat menghambat perkembangan anak, dan berdampak negatif dalam kehidupan selanjutnya seperti penurunan intelektual, memiliki keterlambatan berpikir, rentan terhadap penyakit tidak menular, penurunan produktivitas hingga menyebabkan kemiskinan dan risiko melahirkan bayi dengan berat lahir rendah (UNICEF, 2012; dan WHO, 2010).

Menurut penelitian yang dilakukan oleh Sulastri (2012) bahwa tingkat pendidikan ibu dan tingkat ekonomi mempengaruhi kejadian stunting. Penelitian di Ethiopia Selatan membuktikan bahwa balita yang tidak mendapatkan ASI eksklusif selama 6 bulan berisiko tinggi mengalami stunting (Fikadu, 2014), sedangkan hasil penelitian Aridiyah (2015) juga menunjukkan bahwa faktor yang mempengaruhi terjadinya stunting pada anak balita yang berada di wilayah pedesaan dan perkotaan adalah pendidikan ibu, pendapatan keluarga, pengetahuan ibu mengenai gizi, pemberian ASI eksklusif, umur pemberian MPASI, tingkat kecukupan zink dan zat besi, riwayat penyakit infeksi serta faktor genetik. Oleh karena itu dibutuhkan adanya edukasi untuk meningkatkan pengetahuan, sikap dan perubahan perilaku pada orangtua.

Pengetahuan adalah suatu proses mengingat dan mengenal kembali objek yang telah dipelajari melalui panca indra pada suatu bidang tertentu secara baik (Lestari, 2015). Promosi kesehatan menggunakan media edukasi merupakan salah satu cara yang tepat, guna menyampaikan pesan kesehatan kepada masyarakat. Pemberian penjelasan, demonstrasi dan redemonstrasi pada paket edukasi menstimulasi secara aktif indera penglihatan, pendengaran, perasa dan perilaku, sehingga meningkatkan keberhasilan pembelajaran.

Booklet merupakan suatu media untuk menyampaikan pesan - pesan kesehatan yang berisi tulisan dan gambar dalam bentuk buku. (Suiraoka \& Supariasa, 2012). Selain booklet, 
audiovisual memberikan pengaruh yang sangat besar dalam perubahan perilaku masyarakat. Media audiovisual memiliki dua elemen yang masing-masing mempunyai kekuatan yang akan bersinergi menjadi kekuatan yang besar.

Konsep teori Health Promotion Model (HPM) oleh Nola J. Pender yang memiliki kesesuaian antara karakteristik individu yang dikemukakan dalam teori Nola J. Pender. Pada teori Pender sifat-sifat dan pengalaman individu mempengaruhi perilaku spesifik pengetahuan dan sikap responden yang menjadi tujuan dari penelitian berupa perubahan pengetahuan, sikap dan perilaku orangtua dalam merawat balita stunting (Alligood, 2014)

\section{METODE}

Desain yang digunakan dalam penelitian ini adalah penelitian eksperimen dengan rancangan quasy experimental dengan pre-test and post - testwithout control untuk mengetahui pengaruh metode booklet dan audiovisual terhadap pengetahuan orangtua dalam merawat balita dengan stunting. Besar sampel ditentukan berdasarkan rumus federer, sebanyak 30 responden dibagi dalam 3 kelompok, setiapkelompok terdiri dari 10 responden. Instrumen yang dipakaiberupakuesioner pengetahuan.

Proses pengambilan data dilakukan selama 1 minggu. Kriteria inklusi dari penelitian ini adalah balita dengan usia 24 bulan sampai dengan 60 bulan dengan stunting, orangtua yang tinggal di daerahpesisir di Puskesmas Kota Karang, tidak mengalami gangguan sistem endokrin.

Sebelumd ilakukan proses pengambilan data, orang tuacalon responden diberikan informasi tentang penelitian yang dilakukan, keuntungan dan dampak yang mungkin dapat ditimbulkan selama proses penelitian, bila orang tuacalon respon dan menyetujuinya maka dilanjutkan dengan pengisian lembar persetujuan menjadiresponden. Kelompok pertama diberikan edukasi dengan menggunakan booklet, kelompok keduadiberikan edukasi dengan menggunakan media audiovisual sementara untuk kelompok ketiga diberikan edukasi menggunakan booklet dan audiovisual. Sebelum dilakukan edukasi terlebih dahulu diadakan pretest setelah itu diberikan edukasi tentang merawat balita stunting kepada responden selama 20 menit dengan 2 kali tatap muka. Setelah dilakukan perlakuan, responden kembali diberikan kuesioner sebagai data post-test

Uji statistic menggunakan uji parametric yaitu uji paired sampel t-test untuk menguji perbedaan pengetahuan sebelum dan sesudah dilakukan intervensi. Analisa data menggunakan program komputer

\section{HASIL}

Setelah dilakukan pengukuran pada kelompok intervensi total sebanyak 30 responden

Tabel.1Perbedaanpengetahuansebelumdanses udahedukasidenganmedia booklet danaudiovisual

\begin{tabular}{|c|c|c|c|c|c|c|}
\hline \multicolumn{2}{|c|}{ Variabel } & $N$ & Mean & $S D$ & $\begin{array}{c}\text { Beda } \\
\text { mean }\end{array}$ & p-value \\
\hline \multirow{9}{*}{$\begin{array}{c}\text { Kota } \\
\text { Karang }\end{array}$} & \multicolumn{6}{|c|}{ Edukasidengan media Booklet } \\
\hline & Sebelum & \multirow{2}{*}{10} & 62,50 & 9,789 & \multirow{2}{*}{7,5} & \multirow{2}{*}{0,003} \\
\hline & Sesudah & & 70,00 & 8,819 & & \\
\hline & \multicolumn{6}{|c|}{ Edukasidengan media Audiovisual } \\
\hline & Sebelum & \multirow{2}{*}{10} & 62,50 & 8,898 & \multirow{2}{*}{18,5} & \multirow{2}{*}{0,000} \\
\hline & Sesudah & & 81,00 & 7,379 & & \\
\hline & \multicolumn{6}{|c|}{ Edukasidengan mediabooklet\& audiovisual } \\
\hline & Sebelum & \multirow{2}{*}{10} & 63,00 & 11,832 & \multirow[t]{2}{*}{29,0} & \multirow[t]{2}{*}{0,000} \\
\hline & Sesudah & & 92,00 & 7,888 & & \\
\hline
\end{tabular}

Berdasarkan tabel 1 di atas dapat diketahui bahwa rata-rata pengetahuan orangtua tentang merawat balita stunting sebelum pemberian edukasi menggunakan media booklet adalah 62,50 setelah pemberian edukasi rata-rata pengetahuan orangtuaadalah 70,00 Hasil uji statistic didapatkanp-value $0,003 \quad(\mathrm{p}-<\alpha 0,05)$ artinya pemberian edukasi menggunakan media booklet terbukti efektif meningkatkan pengetahuan orangtua tentang merawat balita stunting.

Setelah pemberian edukasi rata-rata pengetahuan orangtua adalah 65,00 dengan standar deviasi 10,541. Hasil uji statistik didapatkan $p$-value $0,001 \quad(\mathrm{p}$-value $<\alpha 0.05)$ artinya pemberian edukasi menggunakan media audiovisual terbukti efektif meningkatkan pengetahuan orangtua tentang merawat balita stunting dan orangtua tentang merawat balita stunting.

Rata-rata pengetahuan orangtua tentang merawat balita stunting sebelum pemberian edukasi menggunakan media booklet \&audiovisual adalah 63,00dan setelah pemberian edukasi rata-rata pengetahuan orang tua adalah 92,00 . Hasil uji statistic didapatkan $p$-value 0,000 
$(\mathrm{p}-<\alpha 0.05)$ artinya pemberian edukasi menggunakan media booklet \& audiovisual terbukti lebih efektif meningkatkan pengetahuan orangtua.

\section{PEMBAHASAN}

1. Pengaruh edukasi menggunakan media booklet terhadap pengetahuan orangtua tentang merawat balita stunting.

Rata-rata pengetahuan sebelum pemberian edukasi menggunakan media booklet adalah rendah dan setelah pemberian edukasi menggunakan booklet terbukti efektif meningkatkan pengetahuan orangtua tentang merawat balita stunting.

Menurut Lestari (2015) pengetahuan adalah suatu proses mengingat dan mengenal kembali obyek yang telah dipelajari melalui panca indra pada suatu bidang tertentu secara baik. Hasil penelitian Maria Agustin (2014) bahwa ada pengaruh pengetahuan kesehatan setelah dilakukan pendidikan kesehatan menggunakan media booklet. Menurut Notoatmodjo (2010) booklet adalah media penyampaian pesan-pesan kesehatan dalam bentuk buku, baik berupa tulisan maupun gambar.

2. Pengaruh edukasi menggunakan media audiovisual terhadap pengetahuan orangtua tentang merawat balita stunting

Hasil penelitian menunjukan bahwa selisih rata-rata pengetahuan orangtua tentang merawat balita stunting sebelum dan sesudah pemberian edukasi menggunakan media audiovisual lterjadi peningkatan.

Penelitian yang dilakukan oleh Zakaria (2017) mengatakan bahwa ada peningkatan pengetahuan dan sikap setelah diberikan pendidikan kesehatan dengan media audiovisual.

Media audiovisualadalah alat bantu pendidikan yang dalam penggunaannya menstimulus indera penglihatan dan pendengaran yang terdiri dari suara dan gambar yang dapat meningkatkan persepsi, pengetahuan, dan meningkatkan ingatan orangtua. Menurut Maulana (2014) pancaindera yang banyak menyalurkan pengetahuan keotak adalah mata (kurang lebih $75 \%$ sampai 87\%), sedangkan 13\% sampai $25 \%$, pengetahuan manusia diperoleh dan disalurkan melalui pancaindera yang lain.

Pemilihan audiovisual sebagai media penyuluhan kesehatan dapat diterima dengan baik oleh responden. Media ini menawarkan penyuluhaan yang lebih menarik dan tidak monoton. Penyuluhan dengan audiovisual menampilan gerak, gambar dan suara sedangkan penyuluhan dengan media cetak menampilkan tulisan dan suara penyuluh secara langsung yang membuat terkesan formal. Pada saat pelaksanaan penelitian, karena media ini terbilang baru sebagian besar responden mempunyai keingintahuan yang besar terhadap isi video dan melihat video sampai selesai dengan serius.

Peningkatan pengetahuan orangtua setelah diberikan perlakuan merupakan akibat dari pemberian pendidikan kesehatan dengan media audiovisual. Dengan demikian media audiovisual sebagai media pendidikan kesehatan efektif digunakan untuk memberikan peningkatan pengetahuan kepada orangtua menjadi lebih baik. Selain itu juga usia dan paritas orangtua yang mempunya balita stunting pada kelompok audiovisual antara 25 - 30 tahun dan multipara. Usia dapat mempengaruhi daya tangkap dan pola pikir seseorang. Semakin bertambah usia akan semakin berkembang pula daya tangkap dan pola pikirnya, sehingga pengetahuan yang diperolehnya semakin membaik dan orangtua dengan multipara lebih banyak pengalaman dari sebelumnya untuk merawat balitanya.

\section{Pengaruh edukasi menggunakan media booklet \& audiovisual terhadap pengetahuan orangtua tentang merawat balita stunting.}

Hasil penelitian menunjukan perbedaan selisih rata-rata pengetahuan orangtua sebelum dan sesudah pemberian edukasi menggunakan media booklet dan audiovisual terjadi peningkatan. Disimpulkan bahwa pemberian edukasi menggunakan media booklet dan audiovisual terbukti ada pengaruh meningkatkan pengetahuan orang tua tentang merawat balita stunting.

Penggabungan atau kombinasi menggunakan kedua media booklet dan 
audiovisual dalam memberikan edukasi terbukti efektif untuk meningkatkan pengetahuan orangtua dalam merawat balita stunting. Hasil penelitian ini sesuai dengan penelitian yang dilakukan oleh Kapti (2013) tentang media audiovisual dan penelitian Sirait (2013) tentang pemberian informasi menggunakan media booklet, dimana keduanya menyatakan bahwa media penyuluhan baik booklet dan audiovisual sama - sama dapat merubah pengetahuaankearah yang lebih baik.

Pemberian edukasi dengan media audiovisual signifikan mempengaruhi orangtua apabila dilakukan dengan memberikan informasi dengan tatap muka, sehingga akan ada interaksi antara edukator dengan orangtua. Selain itu peneliti menggunakan booklet sebagai media gabungan dengan media audiovisual untuk mendukung jalannya penelitian. Booklet dapat dipelajari disaat santai dan ukurannya yang kecil mudah dibawa, memuat informasi yang detail secara lisan tidak mungkin disampaikan semuanya serta mengurangi kegiatan mencatat.

Peningkatan pengetahuan orangtua tentang merawat balita stuting kemungkinan ini bisa terjadi akibat setelah dilakukan pendidikan kesehatan baik menggunkan media audiovisual yang menarik dengan menggunakan gambar bergerak dan suara atau bahasa yang mudah dipahami secara jelas serta booklet dengan gambar berwarna, tulisan berisikan informasi yang mudah dibaca serta dilakukan diskusi atau tanya jawab sehingga dapat mempengaruhi hasil pengisian pertanyaan kuesioner

Selain itu tingkat pendidikan orangtua juga merupakan salahsatu faktor yang dapat berperan penting terhadaptingkatpengetahuan. Makin tinggi pendidikan seseorang, makin mudah orang tersebut menerima informasi. Dengan pendidikan tinggi maka seseorang akan cenderung untuk mendapatkan informasi, baik dari orang lain maupun dari media massa. Semakin banyak informasi yang masuk semakin banyak pula pengetahuan yang didapat tentang kesehatan. Pengetahuan sangat erat kaitannya dengan pendidikan dimana diharapkan seseorang dengan pendidikan tinggi, maka orang tersebut akan semakin luas pula pengetahuannya serta pengaruh lingkungan yang kondusif saat pendidikan kesehatan menggunakan media audiovisual dan bookletatau kondisi ketika responden duduk pada saat pengisian kuesioner membuat media pendidikan kesehatan tersebut memiliki keefektifan yang lebih baik.

\section{SIMPULAN}

Terdapat perbedaan rata-rata pengetahuan orang tua sebelumdan sesudah diberikan edukasi tentang merawat balita stunting melalui media booklet

Terdapat perbedaan rata-rata pengetahuan sebelum dan sesudah diberikan edukasi tentang merawat balita stunting melalui media audiovisual

Terdapat perbedaan rata-rata pengetahuan sebelum dan sesudah diberikan edukasi tentang merawat balita stunting melalui media booklet dan audiovisual.

\section{SARAN}

Bagi penelitian yang akan datang hendaknya dapat mengembangkan penelitian ini dengan mengambil edukasi booklet dan audiovisual terkaitdengan gizi terhadap feeding practice orangtua dengan balita stunting, faktor - faktor yang mempengaruhi kejadian stunting dan pengaruh gaya hidup, sosial ekonomi terhadap kejadian stunting.

\section{DAFTAR PUSTAKA}

Alligood, M.R. (2014). Pakar tori keperawatan dan karya mereka. Edisi 8 volume 1. Singapore : Elsevier.

Aridiyah, F. O., Rohmawati, N., \& Ririanty, M. (2015). Faktor - faktor yang mempengaruhi kejadian stunting pada anak balita di wilayah pedesaan dan perkotaaan. e-Jurnal pustaka kesehatan, 163-170.

Fikadu, T., Assegid, S., \& Dube, L. (2014). Factor associated with stunting among children of age 24 to 59 month in Meskan district, Gurage Zone, South Ethiopia: a case-control study. BMC Public Health. Doi:10.1186/1471-2458-14-800, 1-7.

Kapti, Rini.E., Rustina, Y., \& Widyastuti. (2013). Efektifitas audiovisual sebagai media 
penyuluhan kesehatan terhadap peningkatan pengetahuan dan sikap ibu dalam tatalaksana balita dengan diare di dua Rumah Sakit Kota Malang. Jurnal Ilmu Keparawatan Volume 1. No $1 \mathrm{Mei}$ 2013; ISSN 2088-6012.

Kemenkes RI. (2018). Situasibalitapendek (stunting) di Indonesia. Kementerian Kesehatan Republik Indonesia.

Kemenkes RI. (2018). Hasil utama Riset Kesehatan Dasar (Riskesda). Kementerian Kesehatan Republik Indonesia: Badan Penelitian dan Pengembangan Kesehatan.

Kemenkes RI. (2017). Buku saku pemantauan status gizi (PSG). KementerianKesehatan RI:

DirektoratGiziMasyarakatJenderalKesehat anMasyarakat

Lestari,Weny.,Kristiana,Lusi., \&Paramita, Astridya. (2017). Stunting: studi konstruksi social masyarakat perdesaan dan perkotaan terkait gizi dan pola pengasuhan balita di kabupatenJember. Aspirasi Vol 9 No 1. 17 $-33$

Maria, Agustina. (2014). Efektifitas pendidikan kesehatan media booklet dibandingkan dengan audiovisual terhadap pengetahuan orangtua tentang karies gigi pada anak usia 5 - 9 tahun di Desa Makam Haji. Diakses dari http://eprints.ums.ac.id

Maulana, H.D.J. (2014). Promosi kesehatan. Jakarta: EGC

Notoatdmojo. (2010). Promosi kesehatan teori dan apliaksi. Jakarta: Rineka Cipta.

Sirait, N.A.J. (2013). Pemberian informasi meningkatkan pengetahuan, sikap dan keterampilan orang tua dalam penanganan demam pada anak. Jurnal Keperawatan Indonesia, Volume 16

Sulastri, D. (2012). Faktor determinan kejadian stunting pada anak usia sekolah di Kecamatan Lubuk Kilangan Kota padang. Majalah kedokteran andalan no. 1 Vol. 36 januari- juni 2012, 39-49

Suiraoka, I., \& Supriana, I. (2012). Media pendidikan kesehatan. Yogyakarta: Graha Ilmu

UNICEF. (2012). Ringkasan kajian gizi Oktober 2012. Jakarta: UNICEF Indonesia.

WHO. (2010). Nutrition landscape information system (NLIS) country profile indicators: Interpretation guide. Geneva: World Health Organization
Zakaria, F. (2017). Pengaruh pendidikan kesehatan dengan media audiovisual terhadap pengetahuan dan sikap ibu tentang inisiasi menyusu dini di Kota Yogyakarta. Diakses dari https://ejournal.unisayogya.ac.id 